\title{
PENGABDIAN KKM DI DESA TURUS KECAMATAN WALANTAKA KOTA SERANG DALAM MENGHADAPI PANDEMI COVID-19 AGAR TETAP PRODUKTIF
}

\author{
Indri Sari Utami, Raka Aditya, Novita Sri Aryani, Renny Monica Putri, Nanda Amelia, \\ Tasyia Aji Septiani, Syifaurrohmah, Siti Widiana, Yuni Amelyani \\ Universitas Sultan Ageng Tirtayasa \\ Email: isu_indrisariutami@untirta.ac.id
}

\begin{abstract}
During the Covid-19 pandemic there were still many people who ignored health protocols and also many were affected by the economy. Therefore, the student work study (KKM) of Sultan Ageng Tirtayasa University is to provide education to the public to be alert, alert and resilient to face the covid-19 outbreak. The population of activities in Turus village is all residents because the intended target is that all residents can carry out health protocols, and those who are productive can create jobs, and those who are still in school can learn well even at home. The method of implementing this KKM is a program oriented towards community assistance in the economic field, exploring local potential, a combination of online media in preparing human resource potential. Some of the results achieved in this service are the understanding of residents about covid-19, how to prevent and make their own personal protective equipment in the form of masks without sewing machines and hand sanitizers, also providing online tutoring for students, and socializing training on making aquaponics for fish and plant cultivation and help create an online media shop to promote citizen entrepreneurship.
\end{abstract}

Keywords: Health protocol, tutoring, aquaponics, kkm untirta

\begin{abstract}
Abstrak
Di masa pandemi covid-19 ini masih banyak masyarakat yang mengabaikan protokol kesehatan dan juga banyak yang terdampak perekonomiannya. Oleh karena itu kuliah kerja mahasiswa (KKM) Universitas sultan ageng Tirtayasa adalah memberikan edukasi kepada masyarakat untuk siaga, sigap dan Tangguh menghadapi bencana wabah covid-19. Populasi kegiatan di desa Turus adalah seluruh warga karena sasaran yang dituju adalah seluruh warga dapat menjalankan protokol kesehatan, dan untuk yang produktif dapat membuat lapangan pekerjaan, serta yang masih bersekolah dapat belajar dengan baik meskipun dirumah. Metode pelaksanaan KKM ini yakni program berorientasi kepada pendampingan masyarakat dalam bidang ekonomi, menggali potensi lokal, kombinasi media daring dalam mempersiapkan potensi sumber daya manusia. Beberapa hasil yang dicapai dalam pengabdian ini adalah pemahaman warga mengenai covid-19, cara mencegah hingga membuat sendiri alat pelindung diri berupa masker tanpa mesin jahit dan hand sanitizer, juga memberikan bimbingan belajar online bagi siswa, dan mensosialisasikan pelatihan pembuatan akuaponik budidaya ikan dan tanaman serta membantu membuatkan media online shop untuk mempromosikan wirausaha warga.
\end{abstract}

Kata Kunci: Protokol kesehatan, bimbingan belajar, akuaponik, kkm untirta

\section{PENDAHULUAN}

Kota Serang merupakan daerah otonom yang terbentuk dari pemekaran
Kabupaten Serang pada tanggal 10

Agustus 2007 berdasarkan UndangUndang Nomor 32 Tahun 2007 tentang 
Pembentukan .Berdasarkan penjelasan undang-undang tersebut dijelaskan bahwa Kota Serang memiliki luas wilayah keseluruhan 266,71km2. Sedangkan hasil inventarisasi luas wilayah di 6 (enam) kecamatan secara faktual luas wilayah Kota Serang seluruhnya mencapai $266,74 \mathrm{~km} 2$ atau sekitar 3,08\% dari luas wilayah Provinsi Banten. Sesuai dengan pasal 5 UndangUndang Nomor 32 Tahun 2007, Kota Serang memiliki batas-batas wilayah sebagai berikut: (1) Sebelah Utara berbatasan dengan Teluk Banten, yang terletak di Kelurahan Banten dan Kelurahan Sawah Luhur; (2) Sebelah Timur berbatasan dengan Kecamatan Pontang di Kelurahan Sawah Luhur, Kecamatan Ciruas, dan Kecamatan Kragilan Kabupaten Serang; (3) Sebelah Selatan berbatasan dengan Kecamatan Cikeusal, Kecamatan Petir, Kecamatan Baros Kabupaten Serang; dan Sebelah Barat berbatasan dengan Kecamatan Pabuaran, Kecamatan Waringin Kurung, Kecamatan Kramat Watu Kabupaten Serang.

Terus meningkatnya kasus positif Covid-19 di Indonesia membuat presiden Joko Widodo mencari cara memutus rantai penyebaran virus tersebut. Total kasus covid-19 hingga 1 Desember 2020 mencapai 543.975 kasus (Moerti,2020). Beberapa pekerja mengalami sistem WFH (Work From Home) dan para pelajar mengikuti pembelajaran secara daring. Beberapa orang kehilangan pekerjaannya karena beberapa perusahaan merugi diakibatkan produknya tidak terjual sebagaimana sebelum adanya virus covid-19 ini.
Cara untuk mengedukasi masyarakat Indonesia mengenai bahayanya virus Covid-19 ini dilakukan dengan banyak cara dari berbagai lapisan masyarakat. Sosialisasi dilakukan melalui sosial media karena sering digunakan oleh masyarakat Indonesia. Adapula yang melalui pertemuan luring tetapi dengan tetap mematuhi protokol kesehatan. Edukasi pencegahan ini sangat penting karena kurangnya kesadaran masyarakat untuk mematuhi protokol covid sehingga kasus penyebaran terus meningkat. Selain pencegahan, diperlukan juga peningkatan produktivitas masyarakat dalam bekerja di rumahnya masingmasing.

Edukasi untuk memutus mata rantai penyebaran covid-19 telah dilakukan pada beberapa sekolah dengan mematuhi protokol kesehatan (Fauzi, 2020). Saat ini semua jenjang sekolah dari TK hingga SMA melaksanakan pembelajaran daring (Pranowo, 2020). Belum ada kejelasan waktu mulai pembelajaran dilakukan secara tatap muka seperti biasa karena terus meningkatnya kasus terpapar virus ini.

Tujuan diadakannya Kuliah Kerja Mahasiswa (KKM) ini adalah untuk membantu masyarakat memahami bahaya covid-19, cara penanggulangannya hingga cara tetap produktif di rumah selama masa pandemi ini. Sosialisasi yang dilakukan adalah melalui sosial media untuk meminimalisir pertemuan dengan banyak orang. Dalam media sosial tersebut juga dibuat rekaman mengenai pembuatan hand sanitizer dengan bahan 
sederhana, pembuatan masker tanpa mesin jahit dan cara mencuci tangan yang baik. Setelah itu akun media sosial tersebut disebarkan kepada warga. Adapun kegiatan pembagian masker dan hand sanitizer, bimbingan belajar online, sosialisasi pembuatan aquaponik dan membuat media online shop.

Desa yang dijadikan lokasi tempat Kuliah Kerja Mahasiswa ini masih kurang memiliki kesadaran dalam mencegah penyebaran covid-19. Hal ini terlihat dari jarangnya warga yang memakai masker dan tidak adanya akses untuk mencuci tangan di tempat-tempat umum. Walaupun desa Turus termasuk Kawasan zona hijau dari covid-19, pihak berwenang seperti kepala desa menghimbau untuk tetap waspada saat menjalani kehidupan sehari-hari. Hal ini dikarenakan penduduk provinsi Banten yang terinfeksi virus corona sudah mencapai 13.215 kasus ditemukan, sejumlah 8.963 dinyatakan sembuh dan 339 meninggal dunia akibat virus ini. Pemerintah tak henti menggalakkan seluruh masyarakat untuk tetap jaga jarak, selalu gunakan masker bila keluar rumah dan selalu jaga pola hidup sehat. Pengabdian untuk meningkatkan kesadaran masyarakat tentang pentingnya menjaga sanitasi diri dan lingkungan ditengah pandemi covid-19 dapat memberikan penguatan terhadap mitigasi dan adaptasi menghadapi pandemi covid-19 (Alifah, 2020).

\section{TINJAUAN LITERATUR}

Penyakit menular akibat infeksi virus coronavirus merupakan virus jenis baru yang muncul pertama kali di Wuhan
Cina yang berasal dari konsumsi daging kelelawar (WHO, 2020). Saat ini dinamakan covid-19 dan sudah menjadi pandemik global (Erlich, 2020). Tandatanda yang kebanyakan muncul jika terserang virus ini adalah demam, batuk kering, dan sesak napas. Adapula beberapa orang yang terinfeksi virus ini tapi tetap sehat dan tidak menunjukkan gejala apapun. Sebagian mengalami kondisi yang semakin buruk hingga kesulitan bernafas dan sebagian lagi dapat pulih dengan imun yang dimiliki oleh tubuh seseorang (WHO, 2020).

Virus covid-19 dapat menular dari orang terinfeksi kepada orang yang sehat melalui droplet yaitu air liur yang keluar dari hidung atau mulut saat seseorang bersin, batuk, bahkan berbicara. Benda mati pun yang terkontaminasi droplet ini dapat menularkan virus ini jika orang lain menyentuhnya lalu menyentuh area mata, hidung dan mulutnya (WHO, 2020). Virus yang membawa covid-19 ini dapat bertahan saat diluar tubuh manusia bergantung dari jenis bahan yang dia kontaminasi. Jika di udara bertahan satu jam, pada benda plastic dan besi tahan karat virus bertahan 72 jam, pada tembaga bertahan 4 jam (Van Doremalen, 2020).

Ada beberapa pencegahan virus covid-19 yang direkomendasikan WHO tahun 2020, antara lain:

1) Mencuci tangan dengan sabun antiseptic dengan air mengalir atau hand sanitizer.

2) Menjaga jarak dengan orang lain minimal satu meter, sehingga harus dihindari kerumunan orang 
3) Jangan menyentuh mata, hidung dan mulut dalam keadaan tangan tidak bersih.

4) Berdiam diri di rumah agar tidak tertular atau menularkan virus ini.

Pentingnya KKM yang bertemakan

peningkatan Kembali produktivitas masyarakat ditengah covid 19 agar masyarakat tetap produktif bahkan membuka usaha baru dalam hal pembuatan produk untuk meningkatkan perekonomian (Tarigan, 2020) selaras dengan pengabdian yang dilakukan. Berikut adalah kegiatan utama yang dilakukan:

1) Sosialisai tentang apa itu covid -19 lewat media sosial

Program kerja ini bermaksud untuk memberikan sosialisasi kepada masyarakat umum mengenai apa itu Covid -19, dan sosialisasi ini kami lakukan melalui media sosial, diharapkan melalui sosialisasi yang telah kami berikan masyarakat jadi lebih paham tentang covid - 19 .

2) Pembuatan Hand Sanitizer dengan bahan sederhana

Kegiatan ini dilaksanakan pada 28 Juli 2020, dan sasaran aksi kegiatan ini adalah masyarakat yang berada di daerah tempat tinggal masingmasing anggota. Dengan adanya kegiatan ini, diharapkan masyarakat tidak lupa untuk mencuci tangan, serta mematuhi protokol kesehatan.

3) Pembuatan masker tanpa mesin jahit

Kegiatan ini dilaksanakan pada 05 Agustus 2020, dan sasaran aksi kegiatan ini adalah masyarakat yang berada di daerah tempat tinggal masing-masing anggota. Dengan adanya kegiatan ini, diharapkan masyarakat selalu memakai masker saat berpergian keluar rumah, serta mematuhi protokol kesehatan.

4) Pembagian masker dan hand sanitizer

Kegiatan pembagian Masker dilaksanakan pada 07 Agustus 2020, sedangkan pemberian hand saitizer dilaksanakan pada 20 Agustus 2020. Sasaran aksi kegiatan ini adalah masarakat umum yang berada di daerah tempat tinggal masingmasing anggota. Namun dalam proses pemberian masker dan hand sanitizer dilakukan melalui perwakilan RT setempat. Dan dengan adanya kegiatan ini, diharapkan masyarakat selalu mematuhi protokol kesehatan, dengan selalu memakai masker serta tidak lupa untuk mencuci tangan dengan menggunakan sabun atau hand sanitizer.

5) Membuat video tata cara mencuci tangan dengan benar

Kegiatan ini dilaksanakan pada 23 Juli 2020, dan sasaran aksi kegiatan ini adalah masyarakat umum. Dengan adanya kegiatan ini, diharapkan masyarakat tidak lupa untuk mencuci tangan, serta mematuhi protokol kesehatan.

Selain kegiatan utama yang menjadi kewajiban seperti dipaparkan diatas, dilakukan juga kegiatan pendukung di lapangan. Program pendukung merupakan kegiatan yang dilaksanakan oleh setiap peserta KKM dimana 
kegiatannya tidak berhubungan langsung dengan penanganan Covid-19 atau merupakan kegiatan untuk membantu masyarakat yang terdampak dari penyebaran Covid-19. Program pendukung ini memiliki beberapa sub tema pilihan yaitu teknologi, kesehatan, pendidikan, pariwisata, ketahanan pangan, lingkungan hidup, kebijakan dan kesadaran hukum, ketahanan ekonomi, dan kewirausahaan. Dari beberapa sub tema pilihan tersebut kami memilih tiga sub tema pilihan yaitu Pendidikan, teknologi, dan ketahanan pangan. Kegiatan pendukung yang dilakukan oleh kami meliputi mengadakan pembagian bibit ikan dan benih tanaman; membuat video cara pembuatan akuaponik; melakukan bimbingan belajar lewat media sosial whatsapp; membuat video tentang tata cara memulai bisnis di media sosial; dan mempublikasikan poster edukasi. Dari beberapa sub tema pilihan yang kami pilih pun dalam pelaksanaan kegiatannya tetap kami kaitkan dengan keadaan saat ini yakni dalam masa pandemi Covid-19 sehingga juga merupakan kegiatan utama kami.

\section{METODE PELAKSANAAN (Materials and Method)}

Adapun tahapan kegiatan yang dilaksanakan dalam pengabdian ini adalah sebagai berikut

1. Tahap Persiapan

Mengunjungi lokasi Desa

Turus Kecamatan Walantaka Serang Banten untuk meminta izin pada kepala desa dan mengkomunikasikan kegiatan apa saja yang akan dilakukan.

2. Tahap Pelaksanaan

Memberikan sosialisasi mengenai covid-19, cara mencegahnya, membuat hand sanitizer, membuat masker tanpa mesin jahit, bimbingan belajar, sosialisasi pembuatan aquaponik yang dilakukan dengan membuat rekaman video kemudian menybarkannya melalui media sosial. Selain itu juga dilakukan kegiatan langsung dengan menemui perwakilan warga untuk pembagian masker, hand sanitizer, dan bibit budidaya ikan dengan aquaponik secara gratis.

3. Tahap Evaluasi

Evaluasi dilaksanakan dengan menanyakan respon kepala desa mengenai warga yang mengikuti kegiatan KKM dan kegiatan-kegiatan yang dilakukan semasa KKM untuk dapat menjadi perbaikan dalam kegiatan selanjutnya.

\section{HASIL DAN PEMBAHASAN}

Saat ini masyarakat sedang menghadapi wabah Virus Corona (Covid-19) yang sangat spesifik namun mempunyai efek kompleksitas yang tinggi, bahkan luar biasa, karena ekspektasinya tidak hanya di dunia kesehatan saja namun merambah semua sendi kehidupan manusia, selain itu tidak hanya terjadi di Indonesia tetapi hampir seluruh dunia merasakan. Hampir semua sendi kehidupan manusia mengalami kelumpuhan; baik itu dunia kesehatan, 
dunia pendidikan, dunia kerja, perekonomian, industri, transportasi, kehidupan sosial-budaya, wisata dan sebagainya. Maka dari itu, Universitas Sultan Ageng Tirtayasa selaku penyelenggara pendidikan tinggi melalui KKM TEMATIK COVID-19, perlu mengambil peran untuk mengedukasi Masyarakat dalam menghadapi permasalahan ini dengan harapan Masyarakat akan segera bangkit, pasca pandemi berakhir. Kendati diketahui sedang terjadi penyebaran Covid-19, oleh karena itu KKM Tematik 2020 mengharuskan mahasiswa untuk melakukan kegiatan di daerah tempat tinggal masing-masing anggota.

Kegiatan yang dilakukan adalah mengajak warga sekitar memahami dengan baik virus corona dan bagaimana cara menghindarinya. Selain itu juga, dilakukan pengabdian lain yang dapat meningkatkan produktivitas masyarakat. Untuk warga yang masih bersekolah, dilakukan pembimbingan belajar online. Warga juga diajarkan cara mempertahankan ekonomi keluarga dengan membuat bisnis online dari hasil alam yang melimpah didaerahnya.

Table 1. Rincian kegiatan beserta Outpun dan Outcome

\begin{tabular}{|c|c|c|c|}
\hline No. & Kegiatan & Output & Outcome \\
\hline 1. & $\begin{array}{l}\text { Penyuluhan covid-19 di era tatanan } \\
\text { baru }\end{array}$ & $\begin{array}{l}\text { Menjelaskan tentang } \\
\text { virus, gejala, dan orang } \\
\text { yang berisiko }\end{array}$ & $\begin{array}{l}\text { Warga memahami virus, } \\
\text { gejala, dan orang yang } \\
\text { berisiko }\end{array}$ \\
\hline 2. & $\begin{array}{lrr}\text { Sosialisasi } & \text { Tata-tata } & \text { Cara } \\
\text { Pembuatan Hand } & \text { sanitizer } & \text { dengan } \\
\text { menggunakan } & \text { bahan } & \text { bahan } \\
\text { sederhana } & & \\
\end{array}$ & $\begin{array}{l}\text { Mencampur Alkohol, } \\
\text { gliserol, h2o2, sama air } \\
\text { suling yang mudah } \\
\text { didapat di apotek-apotek }\end{array}$ & Menjadi Hand sanitizer \\
\hline & $\begin{array}{l}\text { Sosialisasi tentang tata-tata cara } \\
\text { cuci tangan yang baik dan benar }\end{array}$ & $\begin{array}{l}\text { Mahasiswa membuat } \\
\text { video berdasarkan } \\
\text { sumber dari Bethsaida } \\
\text { Hospital }\end{array}$ & $\begin{array}{l}\text { Warga memahami tata- } \\
\text { tata cara cuci tangan yang } \\
\text { baik dan benar }\end{array}$ \\
\hline & $\begin{array}{l}\text { Pembagian masker dan hand } \\
\text { sanitizer Gratis kepada masyarakat }\end{array}$ & $\begin{array}{l}\text { Pembagian Masker } \\
\text { 100pc dan hand sanitizer } \\
\text { 83pc kepada ketua RT }\end{array}$ & $\begin{array}{l}\text { Warga mendapat masker } \\
\text { dan hand sanitizer dari RT }\end{array}$ \\
\hline 5. & Bimbingan belajar online & $\begin{array}{l}\text { Diikuti } 29 \text { siswa SD } \\
\text { kelas } 4,5,6 \text { SMP kelas } \\
7,8,9 \text { dan SMA kelas } \\
10 \& 11\end{array}$ & $\begin{array}{ll}\text { Siswa yang mengikuti } \\
\text { bimbingan belajar online } \\
\text { merasa terbantu } & \text { dalam } \\
\text { memahami } & \text { materi } \\
\text { pelajaran } & \end{array}$ \\
\hline & $\begin{array}{l}\text { Sosialisasi mengenai Aplikasi } \\
\text { pembelajaran online lewat Media } \\
\text { Sosial }\end{array}$ & $\begin{array}{l}\text { Diganti dengan tips } \\
\text { belajar online SIASIK } \\
\text { (kondisikan, waktu, } \\
\text { serius, dan diskusi) }\end{array}$ & $\begin{array}{lr}\text { Siswa merasa } & \text { mudah } \\
\text { memahami } & \text { materi } \\
\text { pelajaran } & \end{array}$ \\
\hline & $\begin{array}{l}\text { Sosialisasi Pelatihan pembuatan } \\
\text { akuaponik budidaya ikan dan } \\
\text { tanaman lewat media sosial }\end{array}$ & $\begin{array}{l}\text { Pemaparan materi untuk } \\
\text { membantu ketahanan } \\
\text { pangan warga kampung } \\
\text { turus dan membantu } \\
\text { ekonomi }\end{array}$ & \begin{tabular}{lrr} 
Warga & \multicolumn{2}{r}{ memahami } \\
pembuatan & \multicolumn{2}{c}{ akuaponik } \\
budidaya & ikan & dan \\
tanaman & lewat & media \\
sosial & &
\end{tabular} \\
\hline
\end{tabular}




\begin{tabular}{rlll}
\hline No. & \multicolumn{1}{c}{ Kegiatan } & \multicolumn{1}{c}{ Output } & \multicolumn{1}{c}{ Outcome } \\
\hline 8. $\begin{array}{l}\text { Penyerahan bibit ikan dan tanaman } \\
\text { kepada masyarakat }\end{array}$ & $\begin{array}{l}\text { Penyerahan bibit ikan } \\
\text { dan tanaman }\end{array}$ & $\begin{array}{l}\text { Warga menggunakan bibit } \\
\text { ikan dan tanaman untuk } \\
\text { membantu ketahanan } \\
\text { pangan warga kampung } \\
\text { turus dan membantu } \\
\text { ekonomi }\end{array}$ \\
\hline $\begin{array}{l}\text { Membuat media online shop dan } \\
\text { mempromosikan hasil wirausaha } \\
\text { warga }\end{array}$ & $\begin{array}{l}\text { Diganti dengan cara } \\
\text { memulai bisnis online } \\
\text { kerajinan bambu yang mulai membuat } \\
\text { melimpah disana }\end{array}$ \\
& & $\begin{array}{l}\text { kerajinan bamboo untuk } \\
\text { dijual online }\end{array}$ \\
\hline
\end{tabular}
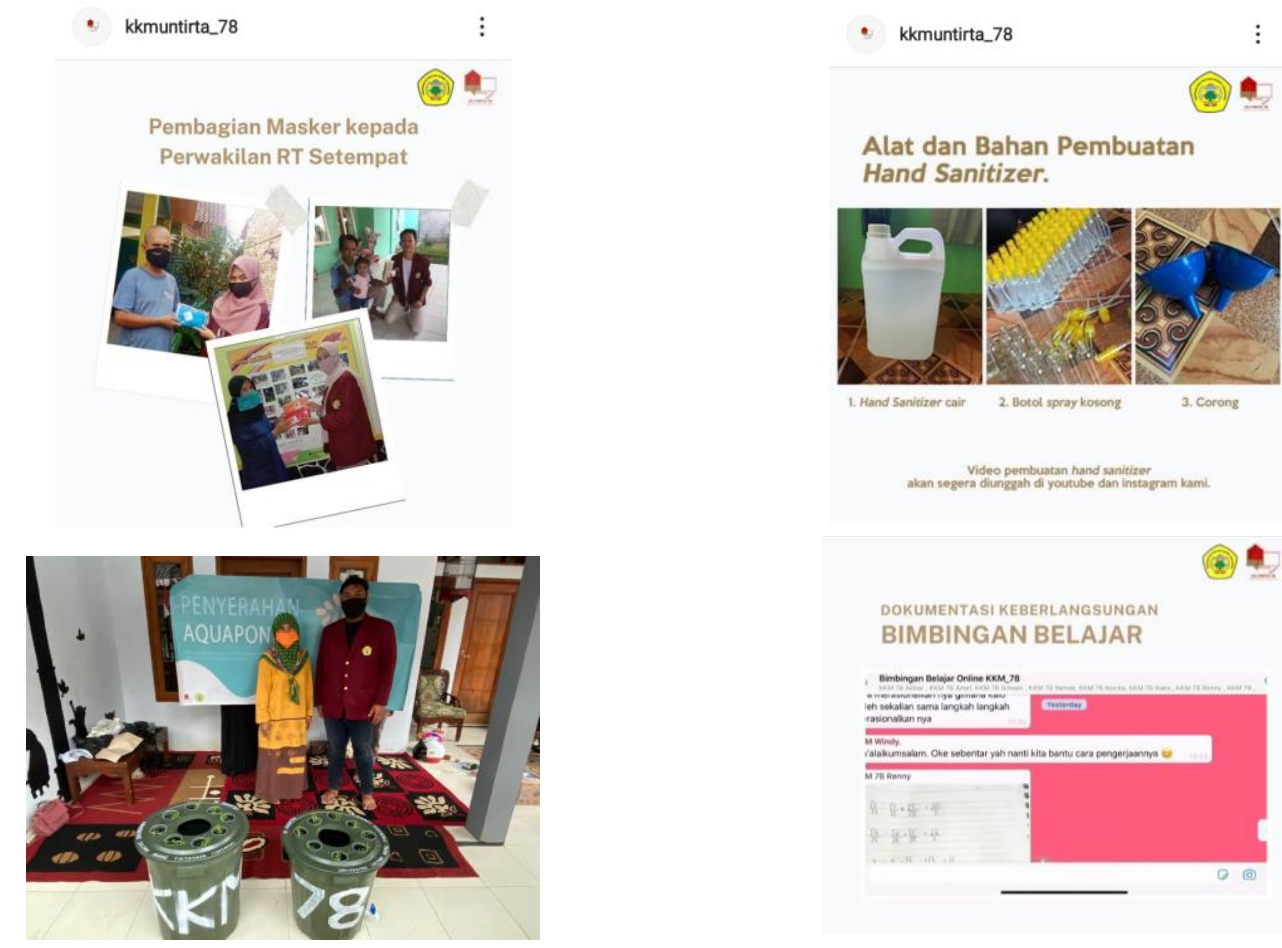

Gambar 1. Pelaksanaan kegiatan Pengabdian KKM

\section{PENUTUP}

Kegiatan sosialisasi dalam kegiatan pengabdian kepada masyarakat ini bertujuan untuk membuat masyarakat Desa Turus memahami tentang covid19, cara pencegahan dan cara tetap produktif di masa pandemi ini. Hal ini dilakukan agar masyarakat Desa Turus dapat terus menjaga kesehatannya baik mental maupun jasmaninya. Saran untuk tindak lanjut dari kegiatan ini adalah:

1. Kegiatan serupa seharusnya dilaksanakan secara kontinyu untuk meningkatkan pemahaman masyarakat tentang pentingnya menjaga diri dari virus corona dan bagaimana cara lebih produktif. 
2. Diadakan Kerjasama dengan instansi yang dapat memberikan bantuan baik dana maupun jasa untuk lebih membantu warga masyarakat.

\section{DAFTAR PUSTAKA}

Alifah, Nur., dkk. (2020). Pendampingan Mitigasi dan Adaptasi Perilaku Baru di Masa Pandemi Covid-19 Melalui Gerakan Masyarakat Menggunakan Masker (GEMAS), Penggunaan Antiseptik dan Desinfektan di Kabupaten Bombana, Sulawesi Tenggara. Engagement: Jurnal Pengabdian kepada Masyarakat, 4(2), 539-550.

Erlich.2020. COVID-19 (Novel Coronavirus). (n.d.). Retrieved May 11, 2020, from https://www.dynamed.com/cond ition/covid-19-novelcoronavirus/

Fauzi, M. (2020, Agustus 05). UMM Beri Edukasi Covid-19 ke Sekolah di Kediri. Retrieved from Republika.co.id: https://republika.co.id/berita/qek bpi380/ umm-beri-edukasicovid19-ke-sekolah- di-kediri

Moerti, Wisnoe (2020, Desember, 01). Data Terkini Covid-19 di Indonesia Desember 2020. Tersedia pada: https://www.merdeka.com/perist iwa/data-terkini-covid-19-diindonesia-desember-2020.html.
Pranowo, G. (2020, 4 16). Alasan Mengapa Menutup Sekolah Sebenarnya Bisa Berbahaya Saat Wabah Corona. Retrieved from TEMPO.CO:

https://www.tempo.co/abc/5394/ alasan- mengapa-menutupsekolah-sebenarnya- bisaberbahaya-saat-wabah-corona

Tarigan, Rehulina. (2020). Kuliah kerja mahasiswa (kkm) di masa pandemi covid-19 sebagai salah satu bentuk pengabdian kepada masyarakat. Jurnal ABDIKARYA, 2(2), 142-157.

Van Doremalen, N., Bushmaker, T., Morris, D. H., Holbrook, M. G., Gamble, A., Williamson, B. N., Tamin, A., Harcourt, J. L., Thornburg, N. J., Gerber, S. I., Lloyd-Smith, J. O., de Wit, E., \& Munster, V. J. (2020). Aerosol and Surface Stability of SARSCoV-2 as Compared with SARSCoV-1. In The New England journal of medicine (Vol. 382, Issue 16, pp. 1564-1567). NLM (Medline). https://doi.org/10.1056/NEJMc2 004973

WHO.2020.Pertanyaan jawaban terkait COVID-19 untuk publik. (n.d.). Retrieved April 28, 2020, from https://www.who.int/indonesia/n ews/novel-coronavirus/qa-forpublic 